Александра Секулић

Филолошки факултет

Универзитет у Београду
821.163.41-1.09 Ристовић А. https://doi.org/10.18485/ai_pesnikinje.2018.ch13

\title{
СПРЕМНОСТ НА СЕПУКУ: ПУТ МАЧА И ПУТ ПЕРА У ПОЕЗИЈИ АНЕ РИСТОВИЋ
}

Самурајски кодекс у поезији Ане Ристовић, нарочито у песничким књигама Уже og иеска (1997) и Забава за gоконе кћери (1999) којима ћемо се овде бавити, присутан је кроз мотиве и песничке слике сугеришући важност овог симболичког кодекса за само певање. Ана Ристовић у сложеној дисциплини духа самураја, неодвојивој од најстрожих вежби тела, препознаје искуство текста као отелотворено искуство бола, писања на кожи чијој белини прети знак у једнакој метафоричкој мери колико и оштрица мача. Владање телом претходи владању пером/ оловком. Алудирајући на Јукиа Мишиму, јапанског писца, песника и, надасве, самураја XX века, песникиња дискретним наговештајима, али и семантички упадљивим траговима ствара јединствену поезију изговорену језиком повреде или, чак, самоповређивања као тајне исписане на кожи. Теоријски ослоњен на Кюиіу о самурајима, затим на Делезово разумевање писања, овај рад је, дакле, посвећен самурајској концепцији у доживљају духовног и телесног у песничким књигама Ане Ристовић.

Кључне речи: самурај, тело, поезија, текст, бол, дисциплина духа и тела.

Песникиња Ана Ристовић спада у ону неколицину савремених аутора о којима када говоримо, онда заиста мислимо на поезију. Ана Ристовић ненаметљиво, аутсајдерски отмено и без агресије малих писаца са 
„великим очекивањима“ упућује на важност свог места у српској књижевности. Од Сновияне воgе (1994) и песничке књиге Уже og иеска (1997), преко Забаве за gоконе кћери (1999), Животиа на разілеgници (2003) и књиге Око нуле (2006) до Метиеорскої ой̄̄aga (2013), изабраних и нових песама у књизи Нешт̄о светили (2014) и Чисиичне (2015) ова поезија негује тематску разноврсност која је, међутим, најприснија са поезијом као таквом, са текстом који само постојање тумачи певањем.

Отуда транспозицију свакодневног прати изазовна иронија, проницљив контраст, динамика „живота на разгледници“ у тренуцима апсолутне непомичности. Еротизам тела у поезији Ане Ристовић представља вербализацију интимног искуства блискости које се не може догодити изван бића и његовог самоисписивања у другом. За поетички сензибилитет песникиње карактеристично је „стање унутрашње емиграције“ како се и сама изразила поводом свог боравка у Словенији. И Ален Бешић, аутор поговора песничке збирке P.S. (2009) наглашава да је управо феномен изгнанства (физичког или духовног, присилног или добровољног) важан „и за парадигматично испољавање и за искушавање другости“ (в. у Ристовић 2009: 141).

О искуству другости која не припада једино бићу изгнаника, поезија Ане Ристовић оставља јединствени траг у књигама Уже og йеска (1997) и Забава за gоконе кћери (1999). Друіо самурајског комплекса, иако присутног у само две песме, изразито заокупља песничку свест. Различите димензије самурајске духовности у спрези са ригорозним третманом тела за Ану Ристовић постају изазови другачије имагинације, другачијег певања. Кроз песме у књизи Уже og йеска уз Мишиму из Забаве за gоконе кћери, које ћемо дакле, неизбежно йомно читати, смењују се перспективе самурајског доживљаја - од се- 
мантичког проширења сепукуа који се најпре јавља између двоје љубавника до потпуне осамљености у самурајској привилегији самонанетог бола.

Сепуку се, хронолошки гледано, у поезији Ане Ристовић најпре јавља између двоје - екслузивно самурајско омогућено је сусретом бића, „Јапанца и Јапанке“, „комшијских подстанара“. Напоменом о сличности са јунацима Мишимине приче „Патриотизам“, одмах се, већ првим стиховима, сугеришу упечатљива атмосфера и значењска прожимања светова. Референцијални простор економично оцртан тек споменом Мишимине приче покреће низ утисака без потребе за гомилањем паралела које се могу пратити. Име Јукиа Мишиме на сличан, ефектан начин започиње интертекстуалну мрежу трагова у обе песме. Једна од најважнијих фигура јапанске културе 20. века - песник, писац, филмски режисер и, надасве, самурај, Мишима је, дакле, у контексту поезије Ане Ристовић, вишеслојна референца. Симболичко згушњавање свих алузија на Мишимино дело изведено је тек бележењем његовог имена. Али, ко су јунаци Анине песме?

Og јуйра gо вечери, / она би савијала итичичие / и жабе / og бојеноі йайира, нижући на нитии / истиочғач$\kappa u x \delta y \delta a-$

Након што је првим стиховима упризорен амбијент, комшијске подстанаре упознајемо у паралелизму њихових заокупљености. Она ниже своје папирне минијатуре чиме се симболички изражава грацилна посвећеност, готово усамљенички рад на нитима нечег посве унутрашњег. Једини одраз тог недоступног дела су мале птице и жабе, фигуре од папира, оригами створења на граници између игре и молитве, разоноде и духовне потребе. Мера „од јутра до вечери“ симболичка је мера њене истрајности једнаке његовом ритму и временском распону. 
Og gоручка gо ручка, он је gубио / из колуйа жу-

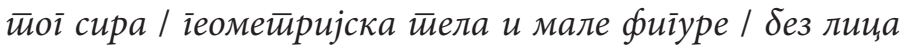
и йола, ређајући / на йаюир, у круї, йажтьво / као gа ирриирема вековно чуgо.

Подједнако брижно, али у гротескној уметности прављења фигура од сира, он се појављује уз ироничну назнаку о преданости која „као да припрема вековно чудо“. Контрапункт припремљен узајамношћу двају принципа, напоредних радњи, остварен је изневеравањем тананости њених фигурина и свилених буба. Али, ово је преокрет који се не догађа да би пресудио, превагнуо у корист једног или другог, женског или мушког. Претпоставка о складу овде није ни постојала да би уопште била изневерена: папирне креатуре и фигуре од сира, Јапанац и Јапанка, све то постоји на хоризонту мимоилажења, неизводљивих размена, али и упорне воље да се оне ипак догоде.

А о йразницима, за заједничком іозбом / сйушйао је gрвени шитайић йоg стио / заgижући јој сукњу и gойирући йамо / їgе би без юеїа морао йореметиитии усираван йоложај иетела, / gостиојансииво обеgне жрииве...

Дрвени штапић као симболички инструмент сусрета заправо указује на премештање самурајског знака. Штапић уместо бодежа или мача, допрети до другог уместо до другости бола и најзад, смрти - целокупна преформулација самурајског дискурса, дакле, доводи до највеће напетости нешто што није тек празнични обед или комшијска љубазност.

Обострана жеља да се отварају једно другом, јер и „она га је водила слободном руком, танком као канџица зебе“ (Ристовић 1997: 36) и избегнута хоризонтала зарад усправног достојанства интензивирају додир који не видимо, али који нам се објављује песничком истином о њему. Извесно је једино пристајање на сусрет, на 
могућност блискости као оно моїуће које није, како би рекао Дерида, тек пука превага над немогућим.

Да ти си очекивао ненајавльени сейуку? / Млаз

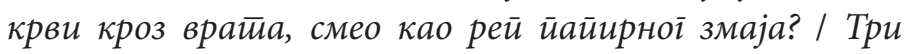
кайи на кимону оне шито је рођенем ољећала gа ће хра-

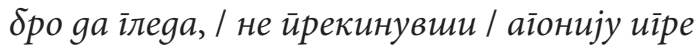

Низом семантичких преокрета самурајских кодова сепуку је поново враћен бићу у самосталности његове одлуке. Ако је питање о очекивању упућено „ненајављеном“, ако тај ненајављени а ипак очекивани не поседује првенство кључног потеза, онда су „три капи крви“ у делокругу сопства, у юеном одговору на Другог који се никада не најављује и увек долази. У игри у којој невиност мора бити изгубљена, песма Ане Ристовић симболички „пресреће“ Другог истовременим силама присности и дистанце, при чему то што се губи није ствар воље и предавања, тихог пристанка на жртву, прећутног одобравања додељених улога. Комшијски подстанари затечени су изузетношћу самурајског преиначења: одједном, онај који приноси дрвени штапић више није онај коме припада бодеж, као што ни она која преузима или боље, наставља, ӣроgужава иницијативу руком танком као „канџица зебе“, више нија та која је „рођењем обећала да ће храбро да гледа, не прекинувши агонију игре“" (Ристовић 1997: 37). Ако су и постојале улоге, оне не само да су замењене, већ су поништене као такве, одбачене зарад најкраћег, неухватљивог трена интимности двају бића у узајамном пристајању једног на друго. Испуњено очекивање сусрета посведочено је траговима крви изван физиологије тела. Јер, ненајављени можда слути и „бодеж у врату, као кљун кога је заборавила одбегла птица“, једна од оних птица које су направиле њене руке, „знајући можда и тада шта губе“ (Ристовић 1997: 37). Бодеж је још увек код 
ње, колико и нежне фигуре и знање о том можgа. Зато се све можgа догађа и све се догодило у чистој могућности препуштања, једино вредном моїћћм, без разлике у странама тако кључним за сваку човекову игру. Јапанац и Јапанка, само на тренутак, дакле врло кратко, док се све не поремети, постају непредочива слика додира, убода, продора који се догодио као целина, као избрисана разлика између ненајављеног и очекиваног, између невиности губитка и губитка невиности. И тај натпросечни тренутак траје тек толико колико допушта контрапунктно распростирање времена у песми.

Разочаране gонеше усииуйне весиии: / она се уgage за службеника фабрике сайова / он йриgоби млаgу ілумииу из Кјотиа / и суши броg-рестиоран на зайаgној обали / їе тетеће рибе збуюују још само gушеке / тьубавних

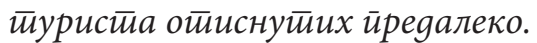

Оно неупоредиво можgа у ком је похрањено симболички привилеговано моїће потиснула је ефемерност свих других, крајње извесних и доступних избора. Глумица и службеник, ресторани и туристи: „ни оштрице достојне срца, ни брода што би изневерио море“ (Ристовић 1997: 37). Ипак, једна блискост која је неизмерљиво кратко трајала не би се могла назрети без самурајског замаха и песничке реинтерпретације сепукуа. Имагинација оштрице самурајског дискурса наставља се и у наредној књизи - Забава за gоконе кћеpu (1999). Доследна ритуалној припреми за смрт, самурајским законима владања собом како би се духовно ирисвојило искуство бола и рањавања, песничка свест се, у некој новој зрелости, поново враћа језику самураја. Овде се драстично мења симболичка употреба елемената борилачког света и самим тим се постижу сасвим другачији уметнички домети.

Песма Мишима дакле, открива упадљиво присутан доживљај коже и са њом повезану самурајску 
визију дисциплине, строгог опхођења према телу као проширеном подручју духа. Нескривена телесност имплицира простор догађаја: нешто важно и посве gpyiо може наћи свој израз, своју симболичку целовитост управо овgе, у поетском окриљу ратничке вештине.

Из вечери у вече, мајка читиа / „Кодекс саму-

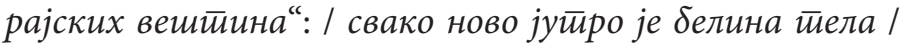
коју ойкрије / растиворени ирни кимоно - / врх сечива

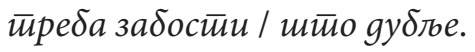

Коgекс самурајских вешишина представља књигу репрезентативних текстова аутора самураја, то су дела самурајске филозофије која читаоца упознаје са ставовима о ратничкој спремности и духовној дисциплини, са начелима борбе, али и принципима стварања.

Дијалог са Мишимом, дакле, прераста у поверљив разговор на самој ивици постојања сугестивно предоченој врхом сечива. И понављања „из вечери у вече“ уводе ритуално читање као симболички супстрат телесне вежбе: ред текста, сплет знакова спрам мишићне констелације. Мишима је аутор есеја Сунце и челик који се, између осталог, налази у Коgексу и говорећи о открићу челика као средства којим је обликовао тело са циљем да регенерише сопствено уметничко стваралаштво, закључује како је развијена мускулатура непотребна савременом човеку „у истој мери колико и класично образовање“ (Mišima 2013: 204). Постепено, мишићи схваћени у смислу духовне и физичке интегралности, постали су антиквитет попут класичне Хеладе. Али, додаје Мишима, „ускрснуће мртвог језика захтевало је челичну дисциплину; да би се тишина преобратила у говор живота, помоћ челика је била неопходна“ (Mišima 2013: 204). Врх сечива, каже Ана Ристовић, треба забости што дубље. Певати значи дискурзивно обележавати болно место, а певати на хоризонту 
самурајских назора значи изнова раскривати белине, рањиве неисписаности и „челичном дисциплином“ подстицати њихов говор. То што треба да проговори, међутим, већ је мртво. Ако се сечиво мора забости што дубље, чему се ова поезија приближава кроз онтолошки парадокс неконвертибилности живота у смрт, бола у текст? Замислимо да сва поезија овог света на неки начин повређује саму себе и сетимо се Настасијевића који је, рецимо то тако, неупоредиви песник ране: Пече $\bar{u} a$ рана / Њоме, и само ғоме, / све gубле жив. Танатолошки комплекс о ком Фројд говори у спрези са еротским, издваја се као наїон за gесйрукцијом, као инстиинкии смр$\bar{u} u$ рекао би Делез, и као такав, он је „суштински нем“. Сва бука живота, каже Фројд, долази од Ероса (Frojd 1994: 102). Песма Ане Ристовић настоји да зађе у тишину смрти, наговештавајући тај непојамни инстинкт сенком оштрице приближене белини коже, неисписивим знаком у покушају да се фиксира писмом.

Са gанима се носитии / као са блиском кожом увек сирремном / на сейуку.

Ако дани значе близину коже, онда је само постојање човеку иманентно, блиско као кожа, присно као све што она открива, а посебно - као оно што скрива. Из тога произилази песнички захтев да управо ова припадност живљења (и Аристотел и Ниче истичу живот као једино искуство постојања доступно човеку) мора, дакле, истовремено бити дубоко лична, неотуђива одлука смрти.

Зар имагинација и уметност мачевања, каже Мишима, нису исто, „јер су технике гајене дружењем са смрћу“ (Mišima 2013: 210). Сепуку није песничка апологија суицида, као што овај чин у самурајском кодексу не призива освету уписану у презрење живота. Кожа се открива болу, повреди и, најзад, смрти, као што се поезија излаже симболичким жариштима немогућег искуства. И певање 
је један вид метафизичког оштећења, отуда текст бележи симболичку нерватуру истина које су од свега што могу бити, најмање болне - и то не због тога што су прешле „с ону страну добра и зла“, већ зато што су још увек и само наше. Истина која заиста не би припадала човеку, а која би га поразила, ућутала би поезију и остварила крај уметности пре почетка Хегеловог краја.

Крај узіллавља, уместио Библије/ gржаити Мишиму чије корице / сличе куйији ов тийових gаччиияа.

Депо симболичких значења која се везују за Мишиму једноставно је исказан поређењем са Библијом. Свети текст је сваки текст који смо суштински одабрали и његова светост произилази из тог осећања сродности, из неодложне потребе поновљених читања.

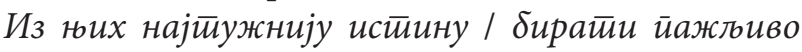
иррстима, као gа је тирешнин ивети / коме се ритиуално, gва мала демона - / gемон сећаға и gемон заборава / кланьају у истио време.

Песничка визија истине као трешњиног цвета и суптилно искуство додира граде контрастну паралелу сечива и прстију, дубоког усецања и обазривог додиривања. Бирати истину, „и најтужнију“, у овом распону семантичких крајности, у узајамном захвату двоструког врхунца, и сепуку и трешњин цвет, открива истину која је већ изабрана. Она је видљива кроз најкраћи интервал времена, између убода који још није смрт и додира који још увек није нежност. Све изван тога је пуко време, ирелевантни и несавладиви чин протицања. Зато се „демон сећања“ и „демон заборава“ истовремено клањају трешњином цвету, истини имагинације и њеног самоукидања.

Из вечери у вече, мајка изучава / самурајске тиајне: йреg сииаване / местиа у книзи обележава иілом / склизнулом низ ирробуђени вулкан / расйлейене йунђе.

Тактилна димензија текста доследно је остварена на нивоу целе песме. Обележавање иглом појачава 
утисак читања које није могуће без интезивних трагова убода, засецања, без изазова упућеног писању које је унапред пристало на губитак жељене мере бола. Потез иглом праћен је слаповима „расплетене пунђе“, путања игле која треба да означи, да боде готово елегантно води кроз вулканску ерупцију власи. Обећање рањавања неодвојиво је од минуциозног трага писања. И, као што лапидарно бележи Мијамото Мусаши, аутор Книіе йей круїова: „Ратник треба истовремено да следи пут мача и пут четкице“ (Musaši 2013: 13), тако једновременост оштрице и писма у поезији Ане Ристовић гради аутентични идеограм стварања. Делез би можда у њему препознао тинију бексиива, писање које налази излаз из замки система, напуштајући непробојне утврде означитеља, измичући и манији тумачења. Поезија Ане Ристовић поседује ову врсту ослобођене имагинације која себи утире пут у непроходност.

Пише се, каже Делез, само љубављу. „Сме се умрети само од љубави, а не неком трагичном смрћу“ (Delez 2009: 68). И сме се писати само том смрћу, упоран је Делез. Писање поезије, писање овакве поезије, у аури самурајске одважности која није плод идеолошког фанатизма, већ резултат скрупулозне херменутике бића, мора изнова обележавати тајне, истине, места у књизи по цену њиховог изневеравања и изгубљене „линије бекства“.

Само она зна: йостиоји / још јеgан, нейисани закон који каже / ga су іооине завесе оg йайирних йииица / кроз

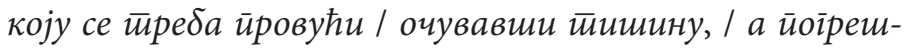
ним речима не затульатии нијеgну.

Поднетии само / блаіи шум малих крила / за леђима.

Последњи стихови песме Мишима готово да су кратак есеј о поезији. Значењски језгровити, формално и интонативно-мелодијски тако су распоређени да граде један целовити мисаони амбијент, истанчану по- 
етичку мапу. На тој мапи, провлачење кроз завесе од папирних птица представља ултимативно кретање без покрета оријентацијом најстроже бираних речи. У есеју Суние и челик Мишима спомиње тренутак када се његов мускулаторни склоп изолује у својој снази, у тој необичној усамљености новостеченог квалитета и описује један „свежи лахор“ на кожи који је учинио да у налету „нежног ваздуха“ ишчезну и сами мишићи. „Па ипак“, наставља Мишима, „они су управо у том тренутку извршили своју суштинску дужност, дробећи невидљивим робусним зубима, тај релативни неодређени осећај постојања уместо ког су успостављали један нов, мистериозни осећај моћи, кристалан, неупоредив“ (Mišima 2013: 207).

Овај доживљај и кристалног и стаменог код Ане Ристовић постоји као симболички дијапазон нагомиланих потреса унутар бића које поврх сечива и извесности рањавања успева да, несумњиво без додира, помиче завесе од папирних птица. Оштрица бодежа инверзна је слика нежности - само треба задржати дах и проћи. Пажљиво, као што су се пажљиво бирале истине, Ана Ристовић ствара поезију у којој се сваки дах рачуна. Једино песници који задрже дах умеју да спрече погрешне речи. Поднети шум „малих крила за леђима“ последњи је напор песничке свести и он се не може извести без писања на граници, без поверења у смрт.

Када Делез замера читаоцима на потреби да пронађу свет у коме ће се кретати поистовећивањем или дистанцом, опредељивањем за и йройив, он само жели да каже како заправо нема света који чека на нас да би био

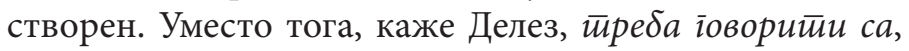
йисати $и$ ca. „То уопште није конверзација, већ конспирација, удар љубави или мржње“ (Delez 2009: 70). Поезија Ане Ристовић настаје у овим симболичким удари-

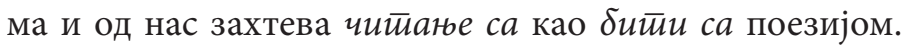


И управо на местима где се јави жеља за маркирањем текста, нека „мала крила“ су нас дотакла, изван тајни и истина, у времену довољно дугом и двољно кратком да може стати на врх оштрице.

\section{Литература}

Delez, Žil. Dijalozi. Beograd: Službeni glasnik, 2013

Milenković, Dragan (ur.) Knjiga o samurajima. Beograd: Tanesi, 2010

Ристовић, Ана. Уже og иееска. Београд: Рад, 1997

Ристовић, Ана. Забава за gоконе кћери. Београд: Рад, 1999

Frojd, Sigmund. S one strane principa zadovoljstva. Novi Sad: Svetovi, 1994

Aleksandra Sekulić

\section{SEPPUKU: THE WAY OF THE SWORD AND THE} WAY OF THE PEN IN POETRY OF ANA RISTOVIĆ

\section{SummarY}

The Samurai codex in the poetry of Ana Ristović, especially in poetry books Uže od peska (1997) and Zabava $z a$ dokone kćeri (1999), which we will deal with here, is present through motifs and poetry images suggesting the importance of this symbolic code for poetry. Ana Ristović in the complex discipline of the spirit of the Samurai, recognizable by the strictest body exercises, describes the experience of the text as an embodied experience of pain, writing on the skin whose whiteness is threatened by the sign in the same metaphoric measure as the blade of the sword. The rule of the body precedes the rule of the pen. Along with Jukio Mishima, a Japanese writer, poet and, above all, 
the Samurai of the 20th century, Ana Ristović with discreet hints, but also semantically striking traces, creates a unique poetry uttered by the language of injury or even self-harm as a secret written on the skin. Theoretically relying on the Book of Samurai, then on Deleuze's understanding of pain and Agamben's philosophical treatment of naked body, this paper is therefore dedicated to the Samurai concept in the perception of spiritual and physical dimensions in poetry of Ana Ristović.

Key words: Samurai, skin, body, poetry, text, pain, discipline of the spirit and body. 